cautious approach to regression, as expressed in your leading article (28 February, p 481), is fully justified.

\section{W M ADAMS}

Department of Pathology, London SE1

' Armstrong, M L, Warner, E D, and Connor, W E, Circulation Research, 1970, 27, 59.

Armstrong, $M L$, and Megan, $M$ B, Circulation Research, 1972, 30, 675

Vesselinovitch, D, et al, Atherosclerosis, 1976, 23, 155.

Adams, C W M, Bayliss, O B, and Turner, D R,

Fournal of Pathology, 1975, 116, 225.

Bailey, J M, in Atherogenesis: Initiating Factors, CIBA Foundation Symposiun

Dondjers, G and Björkerud, S, Artery, 1974, 1 , 3.

Bondjers, G, and Bjorkerud, S, Artery, 1974, 1, 3.

CIBA Foundation Symposium No 12 (NS), p 5. Amsterdam, Elsevier, 1973.

${ }^{8}$ Ghidoni, J J, and O'Neal, R M, Experimental and Molecular Pathology, 1967, 7, 378.

' Adams, C W M, and Bayliss, O B, British fournal of

10 Miller, G J, and Miller, N E, Lancet, 1975, $1,16$.

\section{Prevention of coronary heart disease}

SIR,-In your leading article (10 April, p 853) you draw attention to the fact that high plasma lipids are one of the high-risk markers of coronary heart disease-but you then go on to infer, as does the summary of the Report of the Joint Working Party ( $p$ 881), though perhaps a little less emphatically, that the removal of this high-risk marker removes one of the high-risk causes of the disease. Does it?

A high blood cholesterol level is an even more clearly cut marker in myxoedema and the nephrotic syndrome. Do you do anything towards preventing or curing either of these conditions by lowering the blood cholesterol ? The blood cholesterol level of premenopausa women is higher than that of men of the same age, yet their incidence of coronary heart disease is lower. Why? It seems to me that answers to these questions and perhaps a few others should be forthcoming before we can be expected to proceed with confidence to deprive our patients of such things as cheese, eggs, butter, and cream for the rest of their lives. You have at least not argued, as have some, that it does no harm to lower the blood lipids and it may do good-an argument that migh equally well apply to the use of adrenaline cream and copper bangles for rheumatismbut it would appear that after years of what may justifiably be called determined research this is the only argument left.

A A LEWIS

London W9

\section{Kidneys for transplantation}

SIR,-Dr B Moores and others (13 March, p $629)$ apparently revealed public ignorance of the urgent need of kidneys for transplantation, with few people having made arrangements for their kidneys to be used in the event of their death $(4.8 \%)$, although there appeared to be no lack of goodwill and the vast majority expressed no objection to donation of kidneys. Mr A McL Jenkins (3 April, p 816), however, found that refusal of relatives to allow cadave nephrectomy for transplantation posed the largest avoidable loss of potential kidneys.

There may, of course, be many reasons for this discrepancy, but I would like to stress one point about obtaining permission that has previously received little attention-namely, the timing of seeking permission for removal of kidneys. Recently, in a district genera hospital that had not previously harvested kidneys, permission was obtained on 18 out of 20 occasions for the removal of kidneys, a yield of 18 kidneys for transplantation in year. On both occasions on which permission was declined death had occurred in the accident department immediately after the patient's admission. In the intensive care unit on no occasion was permission refused, and this may in part have been due to a deliberate policy of not seeking permission until a late stage, when the final decision to stop ventilation had already been taken. This usually followed a period of 48 hours' assessment and observation by the medical team treating the patient during which time the tissue-typing of the prospective donor was undertaken. The relatives then had time to adjust to the events of the accident or illness and to see the care and attention of the patient, thus alleviating any anxirty about precipitous termination of the patient's treatment. Circumstances may dictate otherwise, but in a relatively stable sitmation even if the outlook is clearly hopeless it $j:$ perbaps advisable not to seek permission until the very end.

May J also briefly comment on the 11 potential donors in Mr Jenkins's series who died before arrangements for nephrectomy could be made. I do not accept that at least two hours is generally required for preparation before kidney removal. Within our hospital only a very brief period of time is needed for theatre preparation. When the donor is in another hospital the delay may be longer but should only be the time taken for the transplant surgeon to arrive at the hospital where preparations can already have been undertaken. With theatres treating the donor nephrectomy as an emergency and a member of the surgical team always immediately available in the central transplant unit to go out to the donor hospital it should be possible under many circumstances to avoid the loss of kidneys from this delay. In addition, the technique of transplant nephrectomy, while requiring care and attention to detail, is not difficult and should be well within the grasp of most experienced registrars in surgery.

Paul McMaster

University Department of Surgery,

Addenbrooke's Hospital,

Cambridge

\section{Oestrogens as a cause of endometrial carcinoma}

SIR, - Whether or not oestrone and oestrone sulphate have a specific role in relation to endometrial carcinoma, your leading article (3 April, $p$ 791) fails to appreciate the nature of the oestrogens to which women are normally exposed. In particular, information from three laboratories demonstrates that oestrone sulphate is the most abundant form of oestrogen so far discovered in peripheral plasma. ${ }^{1-3} \mathrm{At}$ mid-cycle, for example, its concentration is approximately 5 times that of oestradiol- $17 \beta$ and 15 times that of oestrone. ${ }^{3}$ From this evidence, and using the argument developed in the article that previous exposure for $30-40$ years without harm provides evidence of safety, one might expect oestrone sulphate to be recommended in preference to oestradiol$17 \beta$ and oestriol.
The plasma concentration of oestrone sulphate in postmenopausal women has not, to our knowledge, been reported. The results in the accompanying table demonstrate that exposure to oestrone sulphate continues after ovariectomy when the concentration of each oestrogen is reduced, relative to premenopausal women. Whether the concentration of this steroid in oestrogen-treated postmenopausal women exceeds that found at mid-cycle is not yet known. Simpler analytical methods are required, and some progress is being made in this respect. ${ }^{4}$

The concentration (nmol/l) of oestrone sulphate, oestradiol $-17 \beta$, and oestrone in peripheral plasma from four ovariectomised women who had not received hormone replacement therapy for several months. Values for women at mid-cycle and for men taken from ref 3 are shown for comparison

\begin{tabular}{c|c|c|c}
\hline Subjects & $\begin{array}{c}\text { Oestrone } \\
\text { sulphate }\end{array}$ & $\begin{array}{c}\text { Oestradiol } \\
-17 \beta\end{array}$ & Oestrone \\
\cline { 1 - 2 } $\begin{array}{c}\text { Ovariectomised } \\
\text { women }\end{array}$ & & & \\
1 & 0.38 & $<0.02$ & 0.10 \\
2 & 0.64 & 0.03 & 0.07 \\
3 & 0.33 & $<0.02$ & 0.06 \\
4 & 0.84 & 0.12 & 0.18 \\
Women at mid-cycle & 8.50 & 2.62 & 0.63 \\
5 & 9.20 & 1.63 & 0.53 \\
6 & 2.03 & 0.08 & 0.13 \\
Men & & \\
(mean $\pm \mathrm{SD}, \mathrm{n}=6)$ & \pm 0.85 & \pm 0.02 & \pm 0.02 \\
\hline
\end{tabular}

You assume that treatments with oestradiol$17 \beta$, oestrone, or oestrone sulphate provide different therapeutic effects. Depending on the dosage, this may be correct. However, since these three are in equilibrium in vivo treatment with any one will inevitably expose the patient to the others. ${ }^{56}$ In contrast, oestriol is formed from these oestrogens by an irreversible process. ${ }^{7}$ This feature may be valuable in avoidance of unwanted effects of the other three oestrogens. Selection of an oestrogen for therapy is also complicated by the observations that oestrone sulphate has little affinity for oestrogen receptors of the uterus, at least in the rabbit ${ }^{3}$ and the sheep. ${ }^{8}$ Oestrone sulphate is unlikely to exert oestrogenic activity in this tissue without hydrolysis to oestrone.

We are grateful to Dr M Hartog, Bristol Royal Infirmary, for samples from the ovariectomised patients. The analytical work was supported by the Medical Research Council.

Division of Steroid Endocrinology, School of Medicine,

Leeds

R E OAKEY

Department of Clinical Surgery, School of Medicine, Edinburg

Brown, J B, and Smyth, B J, fournal of Reproduction and Fertility, 1971, 24, 142

Loriaux, D L, et al, Steroids, 1971, 18, 463 .

Hawkins, R A, and Oakey, R E, fournal of Endocrinology, 1974, 60, 3.

Sanyaolu, A A, et al, Proceedings of the 145th meeting of the Society for Endocrinology, London, 1975 Metabolism, 1972, 34, 113 .

Ruder, H J, et al, fournal of Clinical Investigation $1972,51,1020$

Brown, J B, Fournal of Endocrinology, 1957, 16, 202. Shutt, D A, and Cox, R I, fournal of Endocrinology 1972, 52, 299.

\section{Incidence of endometrial carcinoma}

SIR,-You were recently kind enough to notice a paper of ours ${ }^{1}$ in a leading article (3 April, p 792), attributing to it the suggestion that there had been no increase in the incidence 